\title{
Pemberdayaan masyarakat hidup sehat bebas vektor nyamuk melalui konsep ecohealth village berbasis education for sustainable development
}

\section{Giyantolin ${ }^{*}$, Soenarwan Hery Poerwanto ${ }^{\circ}$, Azinuddin Ikram Hakim, Robi Wibowo, \& Muflihah Abustani}

Universitas Gadjah Mada

*giyantolin@gmail.com

\begin{abstract}
On 2018, the incidence of Dengue Hemorrhagic Fever (DHF) occurred in Sukoharjo District, which reached 42 villages with the highest in Sukoharjo District, one of which was in Kelurahan Kenep. More understanding is needed about the education of the dangers of mosquitoes, the characteristics of breeding and the formation of movements, namely through active, creative, innovative and solutive community empowerment. The establishment of the program carried out was the empowerment of mosquito-free healthy communities through the Ecohealth Village concept based on Education for Sustainable Development, which is tied to social, environmental and economic. This program is also carried out with the prevention of various perspectives, such as the use of used materials as mosquito traps, the spread of anti-mosquito plants, and movement of posters to encourage people to live mosquito-free healthy lives and the establishment of one Jumantik Monitoring Household. The results of this program influence the understanding of creative, innovative education and solutions to mosquitoes. During and post-implementation, there have been no cases of dengue. The program provides a significant influence in realising a mosquito-free healthy village.
\end{abstract}

\begin{abstract}
Abstrak Tahun 2018 insiden Penyakit DBD terjadi di Kabupaten Sukoharjo yang mencapai 42 Desa dengan tertinggi di Kecamatan Sukoharjo salah satunya di Kelurahan Kenep. Diperlukan pemahaman tentang edukasi bahaya nyamuk, karakteristik perindukan dan pembentukan gerakan yaitu melalui pemberdayaan masyarakat yang aktif, kreatif, inovatif dan solutif. Pembentukan program yang dilakukan yaitu pemberdayaan masyarakat sehat bebas nyamuk melalui konsep Ecohealth Village berbasis Education for Sustainable Development yang terikat pada sosial, lingkungan dan ekonomi. Program ini juga melakukan pencegahan berbagai perspektif seperti pemanfaatan bahan bekas sebagai ovitrap (perangkap nyamuk), penyebaran tanaman antinyamuk dan pergerakan poster untuk menghimbau masyarakat hidup sehat bebas nyamuk serta pembentukan satu Rumah Tangga (RT) satu Juru Pemantau Jentik (Jumantik). Hasil dari program ini memberikan pemahaman secara edukasi kreatif, inovatif dan solutif terhadap nyamuk. Selama pelaksaan maupun pasca-pelaksaan belum ada kasus DBD. Dengan hal tersebut, program ini memberikan pengaruh dalam mewujudkan Desa sehat bebas vektor nyamuk.
\end{abstract}

Keywords: dengue hemorrhagic fever; mosquito; healthy village; Sukoharjo; community empowerment

\section{OOPEN ACCESS}

Citation: Giyantolin, S. H. Poerwanto, A. I. Hakim, R. Wibowo, \& M. Abustani. 2019. Pemberdayaan masyarakat hidup sehat bebas vektor nyamuk melalui konsep ecohealth village berbasis education for sustainable development. Riau Journal of Empowerment 2(2): 61-69 https://doi.org/10.31258/raje.2.2.61-69

Paper type: Community service

Received: 2019-07-30, Revised: 2019-09-14, Accepted: 2019-09-18

Language: Bahasa Indonesia (id)

ISSN 2623-1549 (online), 2654-4520 (print)

(C) 2019 Giyantolin et al. The article by Author(s) is licensed under a Creative Commons Attribution 4.0 International License. This license permits unrestricted use, distribution, and reproduction in any medium, provided the original author and source are credited. 


\section{PENDAHULUAN}

Kesehatan merupakan hal penting yang harus dimiliki oleh setiap manusia. Kondisi tubuh yang sehat dapat meningkatkan aktivitas manusia menjadi lebih baik. Semua aktivitas manusia sangat bergantung pada kesehatan. Akan tetapi, kesehatan manusia selalu dikerumuni oleh berbagai penyakit yang berasal dari bakteri maupun virus. Penyakit tersebut juga dibawa oleh vektor pembawa. Salah satu vektor pembawa yang cukup berbahaya adalah nyamuk.

Nyamuk memiliki peran yang cukup besar untuk menjadi vektor penyakit. Dari 457 jenis nyamuk dengan 18 marga yang terdapat di Indonesia, didominasi oleh marga Aedes, Anopheles dan Culex yang mencapai 287 jenis. Berbagai jenis penyakit yang timbul akibat vektor nyamuk ini adalah Plasmodium (Malaria), Filaria (Filariasis), Dengue (Demam Berdarah), Zika, dan Cikungunya. Akan tetapi, yang biasa menjadi masalah kesehatan masyarakat di seluruh dunia, khususnya di negara-negara tropis dan sub tropis, adalah Demam Berdarah (DB) dan Demam Berdarah Dengue (DBD) (Suwito, 2008).

Dahulu penyebaran nyamuk di Indonesia pertama kali ditemukan di Kota Surabaya pada tahun 1968 yaitu sebanyak 58 orang terinfeksi dan 24 orang di antaranya meninggal dunia (Angka Kematian (AK): 41,3\%). Sejak saat itu, penyakit yang disebabkan oleh nyamuk ini tersebar luas di seluruh Indonesia (Kementerian Kesehatan RI, 2010).

Penyakit Demam Berdarah Dengue (DBD) merupakan salah satu masalah utama kesehatan di Indonesia, khususnya di wilayah Jawa Tengah yang kini menjadi peringkat ke-3 setelah Jawa Barat dan Jawa Timur, namun kasus meninggal Jawa Tengah berada di posisi ke-2 setelah Jawa Timur (Kementerian Kesehatan RI, 2018). Kondisi seperti ini akan menjadikan perhatian yang lebih bagi masyarakat Indonesia khususnya Jawa Tengah. Selain itu jumlah kabupaten/kota yang terkena kasus DBD belum mengalami penurunan hingga 2018 (100\%) (Kementerian Kesehatan RI, 2019).

Kabupaten Sukoharjo sebagai salah satu Kabupaten/kota yang berada di Jawa Tengah yang memiliki potensi sebagai perkembangan penyakit Demam Berdarah Dengue (DBD). Hal ini karena angka kematian/Case Fatality Rate (CFR) sebesar 1,6 \% diatas target nasional $<1 \%$ (Dinas Kesehatan Jawa Tengah, 2017). Selain itu Kabupaten Sukoharjo mengalami peningkatan pada tahun 2015 sebanyak 315 kasus dengan kasus tertinggi di Kecamatan Sukoharjo (Dinas Kesehatan Kabupaten Sukoharjo, 2016). Pada kecamatan ini yang cukup memprihatinkan dalam kasus DBD yaitu daerah Keluarahan Kenep, dikarenakan terdapat kasus DBD setiap tahunnya.

Kelurahan Kenep merupakan kelurahan yang terletak di Kecamatan Sukoharjo terbagi menjadi 3 bagian lingkup kesehatan, yaitu Lingkungan 1, Lingkungan 2, dan Lingkungan 3. Setiap tahun Kelurahan Kenep terdapat kasus DBD di Lingkungan 2, khususnya wilayah perumahan (RW 9). Hal ini terjadi karena kepadatan penduduk dan kurangnya kesadaran masyarakat akan kebersihan. Upaya penanganan atau pencegahan kasus yang meluas di kelurahan ini sering dilakukan dengan fogging atau pengasapan. Beberapa warga pun masih menggunakan bahan kimia lain yang dapat membuat nyamuk menjadi resisten.

Oleh sebab itu, dibutuhkan suatu inovasi yang solutif, kreatif, dan inovatif serta ramah lingkungan berupa program pemberdayaan masyarakat dalam rangka mewujudkan Desa Bebas Nyamuk Berbasis ESD (Education for Sutainable Development) di Kelurahan Kenep Sukoharjo, Jawa Tengah. Pemberdayaan ini merupakan usaha untuk mewujudkan desa sehat bebas vektor nyamuk dengan sistem ESD. Pemberdayaan masyarakat hidup sehat, artinya dalam perwujudan konsep Desa Sehat tersebut masyarakat di dalamnya juga memiliki sikap kesadaran tinggi tentang kesehatan fisik maupun lingkungan khususnya di dalam kasus DBD.

Melalui konsep Education for Sustainable Development, penulis berupaya menerapan konsep pemeberdayaan masyarakat sehat bebas nyamuk di Kelurahan Kenep. Education for Sustainable Development (ESD) ialah konsep yang dicanangkan UNESCO (2005) tentang pemberdayaan warga melalui pengetahuan, nilai, kebiasaan yang bermuara pada kehidupan yang lebih baik. 
Konsep ESD merupakan konsep yang menekankan pada pendidikan yang berkelanjutnya, artinya berkelanjutan dalam segala aspek yakni terkait parameter aktivitas sosial, lingkungan, dan kemajuan ekonomi. Konsep ESD ini coba penulis dialogkan dengan konsep pemberdayaan masyarakat sehat dalam kaitannya dengan penerapan pemberdayaan masyarakat Kenep secara langsung. ESD diterapkan dalam sosialiasi yang berkelanjutan terhadap partisipasi masyarakt secara aktif, sebab hal ini berimplikasi pada faktor lingkungan dan kemajuan ekonomi. Ketika konsep ESD ini menyokong berdirinya pemberdayaan masyarakat sehat maka yang diharapkan yakni adanya kesadaran warga terkait pentingnya kesehatan dan terbebasnya dari vektor nyamuk, secara tidak langsung dalam penerapan ini juga berdampak pada lingkungan yang semakin asri, dan produktifitas kerja masyarakat.

Edukasi ini akan melibatkan masyarakat agar berperan aktif untuk mengurangi dan mencegah penyakit dari vektor nyamuk (DBD, Malaria, Filariasis serta Cikungunya) sehingga tercipta desa sehat yang bebas dari vektor nyamuk. Selain kesehatan dan lingkungan, sistem ESD juga mempertimbangkan pemberdayaan secara ekonomi melalui potensi yang dimiliki oleh Kelurahan Kenep, Sukoharjo Jawa Tengah. Berdasarkan hal tersebut, program pemberdayaan masyarakat sehat bebas nyamuk diharapkan mampu membawa dampak kesehatan yang lebih baik. Ketika kesehatan masyarakat membaik maka hal ini berimplikasi kepada banyak hal lain, seperti produktifitas kerja, peningkatan ekonomi serta berkembangnya kreatifitas dan seni, sehingga program pemberdayaan masyarakat sehat dalam mewujudkan desa sehat bebas nyamuk tersebut dapat terwujud dan memberikan inspirasi terhadap masyarakat lain agar muncul kesadaran mengenai pentingnya kebersihan lingkungan.

\section{METODE PENERAPAN}

\section{Waktu dan Tempat Pelaksanaan}

Pelaksanaan pemberdayaan masyarakat dilakukan di Kelurahan Kenep, Sukoharjo, Jawa Tengah. Pelaksaanaan program dilaksanakan bulan Juni-Agustus 2018.

\section{Metode Pelaksanaan}

Program pemberdayaan masyarakat dilakukan secara aktif, kreatif dan inovatif. Hal ini bertujuan untuk meningkatkan kreativitas masyarakat dalam mewujudkan desa sehat. Metode pelaksanaan program ini mengacu pada Giyantolin et al. (2018) dengan memodifikasi tambahan untuk program sesuai kondisi lingkungan Kelurahan Kenep, Sukoharjo yaitu sebagai berikut:

\section{Pra-Pelaksanaan}

Pra pelaksanaan berisi kegiatan mengenai hal-hal yang disiapkan sebelum melakukan program.

a. Survei Kelompok Sasaran. Menetapkan kelompok sasaran dalam melaksanakan program. Hal ini dilakukan dengan diskusi dengan perangkat desa untuk mengetahui hasil dialog dengan masyarakat Kelurahan Kenep berupa data-data, kondisi terkini Kenep, kesanggupan dan persetujuan warga dalam perancangan program bersama. Data penting lain yang didapatkan yakni data pemberdayaan kader jumatik, dusundusun yang terkena penyakit dari vektor nyamuk (kasus terbanyak), dan sekolahsekolah sekitar. Hal ini penting untuk pemetaan dalam penerapan program pemberdayaan masyarakat sehat dalam menciptakan generasi emas cinta lingkungan dan kesehatan sehingga hidup sehat bebas vektor nyamuk.

b. Persiapan Sarana dan Prasarana. Tahap ini mempersiapkan sarana dan prasarana dalam mendukung kegiatan pengabdian masyarakat seperti tempat berlangsungnya kegiatan dan alat-alat yang mendukung pemahaman masyarakat saat pelaksanaan program. 
1) Pembuatan Poster Unik dan Menarik. Poster yang dibuat adalah bentuk yang menarik sehingga dapat mengikat para pembaca untuk anak-anak, dewasa maupun orang tua. Poster-poster ini di tempatkan di lingkungan yang biasanya sering dilalui oleh masyarakat. Poster yang terpasang diharapkan dapat memberikan kesadaran masyarakat.

2) Pembuatan Form Jumantik. Permasalahan yang muncul dalam masyarakat yaitu pendataan jumantik dalam memantau jentik-jentik dan seringnya kehilangan data. Untuk itu, perlunya sistem pembuatan form jumantik. Kemudian pembuatan form jumantik ini juga bukan hanya sekedar membuat, namun dibuat secara menarik.

3) Pembuatan Alat Perangkap Nyamuk. Alat perangkap nyamuk biasanya disebut ovitrap. Alat ini berfungsi untuk membantu dalam merangkap nyamuk, sehingga nyamuk ini tidak dapat berkembang biak lagi. Alat yang dibuat juga memiliki fungsi masing-masing yaitu perangkap dalam rumah, luar rumah dan khusus nyamuk dewasa (jantan).

4) Tanaman Anti Nyamuk. Tanaman memiliki berbagai manfaat bagi manusia. Salah satunya manfaatnya adalah beberapa tanaman dapat digunakan sebagai anti nyamuk. Hal ini berfungsi untuk mengusir nyamuk dengan kondisi tanaman mengeluarkan bau yang baik bagi mereka dan dapat membuat nyamuk tidak tahan akan pergi dari lingkungan tersebut. Tanaman yang disiapkan disini adalah Lavender, Zodia, Sere dan lainnya.

Semua perangkat yang dibuat ini guna untuk mensukseskan program dalam memberikan kesadaran masyarakat dan mengoptimalkan pencegahan penyakit yang disebabkan oleh vektor nyamuk.

\section{Pelaksanaan}

a. Penyuluhan Umum dan Pembentukan Kader Jumantik. Penyuluhan pertama dilakukan secara general kepada masyarakat umum yang dilakukan di Aula Kantor Kelurahan Kenep, Sukoharjo. Program saat ini dilakukan dengan pemberian materi kepada masyarakat tentang nyamuk yang berpotensi sebagai pembawa vektor (Aedes sp., Anopheles sp. Culex sp. dan Mansonia sp.), cara pengendalian nyamuk, pemanfaatan barang bekas yang sebagai tempat perindukan nyamuk menjadi bahan berguna, dan menjaga lingkungan tetap bersih dan sehat dari nyamuk.

Disamping itu, pembentukan kader Juru Pemantau Jentik (Jumantik). Pembentukan ini dilakukan atas dasar kondisi masyarakat dalam menangani kasus DBD, sehinga di perlukan minimal 1 orang 1 RT. Hal tersebut bertujuan untuk meringankan dalam melakukan sidak jentik atau pemantauan.

b. Penyuluhan Masyarakat. Penyuluhan ini dilakukan secara lanjutan dengan kondisi daerah yang terbagi menjadi 3 yaitu lingkungan 1, lingkungan 2 dan lingkungan 3 . Penyuluhan saat lanjutan diberikan arahan cara membuat alat perangkap nyamuk dan pembudidayaan tanaman anti nyamuk serta pertanyaan-pertanyaan yang mungkin masyarakat masih merasa bingung dengan kasus-kasus DBD atau penyakit lainnya yang disebabkan oleh nyamuk.

c. Penyuluhan Sekolah. Penyuluhan sekolahan yang dilakukan yaitu beberapa sekolah sekitar Kelurahan Kenep seperti SD N 1 Kenep, SD N 2 Kenep, dam SD N 3 Kenep.

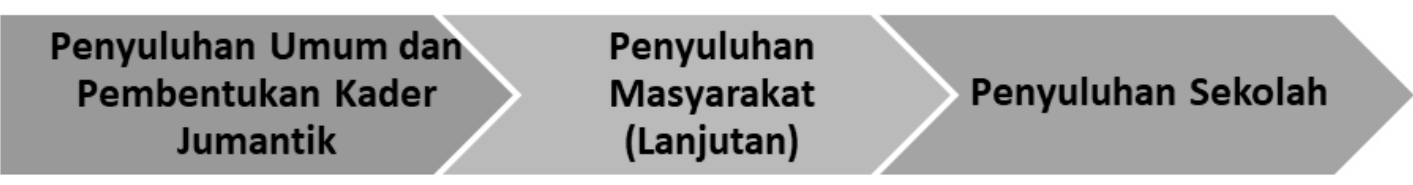

Gambar 1. Alur Pelaksanaan Program Pengabdian 


\section{Pasca-Pelaksanaan}

Dalam beberapa bulan pendampingan akan selalu dilakukan evaluasi demi keberlanjutan program, kami berharap kasus demam berdarah, malaria, dan penyakit-penyakit yang dibawa oleh nyamuk dapat berkurang, bahkan tidak terjadi kembali. Sehingga kami menganggap masyarakat Kenep, Kabupaten Sukoharjo telah berhasil menjalankan program pemberantasan nyamuk sebagai vektor penyakit.

\section{Analisis Data}

Dalam analisis data, data yang telah terkumpul dan diperoleh, diperiksa dan dianalisis serta dibandingkan dengan data-data lainnya yang berkaitan dengan topik yang disusun. Dengan studi kasus, tahapan analisis data berupaya untuk menelaah lebih dalam kasus-kasus yang telah terjadi serta mengaitkannya dengan data-data lain. Dalam penulisan ini, kasus DBD di Sukoharjo masih memiliki angka yang tinggi, belum lagi pendapat masyarakat Kenep yang selalu menghadapi permasalahan dengan DBD.

Proses analisis data adalah proses memberikan makna atau memaknai data dengan mengatur, mengurutkan, mengelompokkan, memberi kode atau tanda, dan mengkategorikannya menjadi bagian-bagian berdasarkan pengelompokan tertentu sehingga diperoleh suatu temuan terhadap rumusan masalah yang diajukan. Data-data mengenai pembahasan tentang nyamuk, DBD, masyarakat Kenep, kesehatan, lingkungan, ESD, ekonomi kreatif, tersebut dikumpulkan dan dikateogrisasi, serta dianalsisis guna penerapan program. Dengan demikian, dapat diperoleh informasi baru dalam pengimpletasian gagasan program. Kemudian, hasil data tersebut digunakan sebagai rujukan untuk dievaluasi dalam memperbaiki program serta pengaplikasiannya.

\section{HASIL DAN KETERCAPAIAN SASARAN}

Kelurahan Kenep memiliki luas wilayah +/-282,1535 Ha. Batas sebelah utara Kenep yakni terdapat Kelurahan Combongan, sebelah selatan terdapat Desa Pojok, Kec. Tawangsari, Sebelah Barat terdapat Desa Tangkisan, Kec. Tawangsari, sedangkan sebelah timur terdapat Kelurahan Banmati. Kelurahan Kenep memiliki jumlah penduduk 4274 jiwa (1098 KK), terdiri dari 2141 laki-laki dan 2133 perempuan. Kelurahan Kenep terbagi menjadi sembilan RW, yakni Desa Kedunggudel, Desa Bangkekan, Desa Kenep, Desa Soko, dan Perum Kenep. Sebelah wilayah Selatan di dominasi permukiman, sedangkan di wilayah utara banyak lahan pertanian.

Penyakit Demam Berdarah merupakan penyakit menular akut yang penyebarannya terjadi di hampir seluruh wilayah Indonesia. Tak terkecuali, Kelurahan Kenep, salah satu desa yang asri di Kecamatan Sukoharjo Jawa Tengah. Menurut Dainur (1992) kehidupan nyamuk Aedes aegypti sangat dipengaruhi oleh lingkungan biologis dan lingkungan fisik. Pengaruh lingkungan biologis misalnya berupa air yang lama disimpan dalam container, biasanya terdapat patogen dan parasit yang mempengaruhi pertumbuhan larva nyamuk. Sedangkan pengaruh fisik dapat berupa tata rumah, macam container, ketinggian tempat, iklim, dan geografis. Pengaruh yang lain misalnya berupa pengaruh hujan, yang dapat menyebabkan kelembaban naik dan menambah jumlah tempat perindukan. Kasus demam berdarah dengue lebih cenderung meningkat selama musim hujan (Dainur, 1992).

Selaras dengan yang dikatakan Dainur, kondisi lingungkan Kenep merupakan tempat yang mudah bagi nyamuk untuk berkembang biak. Selama dua bulan penulis survey dan sosialisasi kader Jumantik, penulis menemukan lingkungan yang kurang bersih, kesadaran pemahaman masyarakat yang kurang terhadap pentingnya kesehatan, ditambah faktor geografis dan faktor biologis yang semakin menambah faktor berkembang biaknya nyamuk di Kenep.

Sebenarnya pemerintah telah berupaya banyak dalam hal menggerakkan dan mengedukasi masyarakat dengan adanya Program Gerakan Masyarakat Sehat (GERMAS) dan Perilaku Hidup Bersih dan Sehat (PHBS) yang telah selalu digencarkan untuk mengatasi peningkatan 
penyakit DBD dan perkembangbiakan nyamuk. Akan tetapi, dalam pelaksanaan program tersebut masih belum optimal terbukti dengan masih banyaknya kasus DBD, dan belum berkurangnya angka bebas jentik dan nyamuk dewasa secara signifikan. Itulah sebabnya diperlukan program pemberdayaan masyarakat hidup sehat dengan sistem ECOHELATH VILLAGE dicanangkan oleh Giyantolin et al. (2018) demi mewujudkan desa bebas vektor nyamuk.

Pemberdayaan masyarakat ini juga dilatarbelakangi dengan permasalahan yang ada, seperti nyata yang ada sampai seakarang ini masih terjadi penyebaran wabah penyakit DBD maupun Malaria terutama di Kelurahan Kenep, Sukoharjo, Jawa Tengah. Untuk itu diperlukannya suatu solutif yang dapat mengajak masyarakat untuk lebih paham terhadap kesehatan tubuh melalui kondisi lingkungan. Masyarakat masih perlu dibimbing mana yang lebih baik dan mana yang harus ditinggalkan sehingga menunjang kesehatan yang lebih baik, serta tak lupa kata "Mencegah Lebih Baik daripada Mengobati". Dengan demikian, solusi pemberdayaan masyarakat yaitu membuat program desa sehat dengan suatu edukasi aktif, kreatif dan inovatif serta menarik, sehinga diharapkan memberikan efek yang lebih menyenangkan untuk belajar tentang kesehatan terutama pada pembawa vektor nyamuk.

Dalam pelaksanaan program dilakukan beberapa tahapan yaitu penyuluhan umum dan pembentukan kader jumantik, penyuluhan lanjutan kepada masyarakat, dan penyuluhan kedalam sekolah.
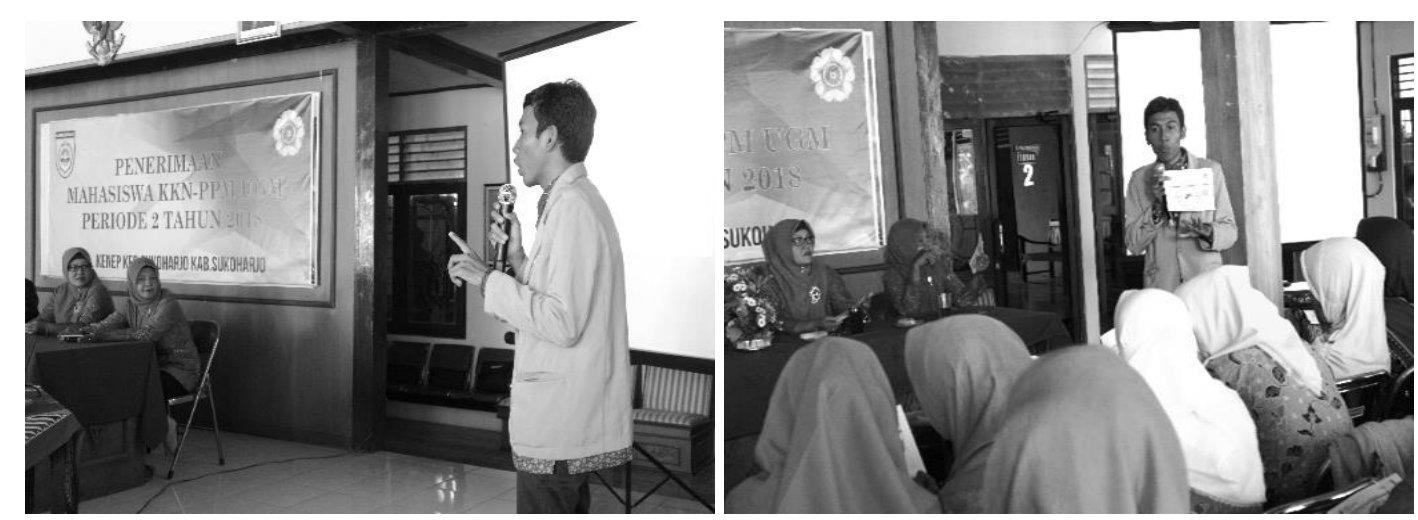

Gambar 2. Pemberian materi tentang bahaya nyamuk dan cara penanggulangannya

Penyuluhan umum yang dilakukan yaitu dengan pemberian materi-materi secara detail tentang nyamuk, bahaya nyamuk, karakteristik tempat perindukan nyamuk, pemanfaatan bahan bekas menjadi barang berguna dan pemberian semangat dalam menanggulangi penyakit akibat nyamuk. Selain itu dilakukan dengan pembentukan kader juru pemantau jentik (Jumantik). Hal ini dilakukan untuk memberikan arahan untuk siap dan sigap dalam mengatasi perkembangan nyamuk dan penanggulangannya yaitu dengan 1 RT 1 Jumantik.

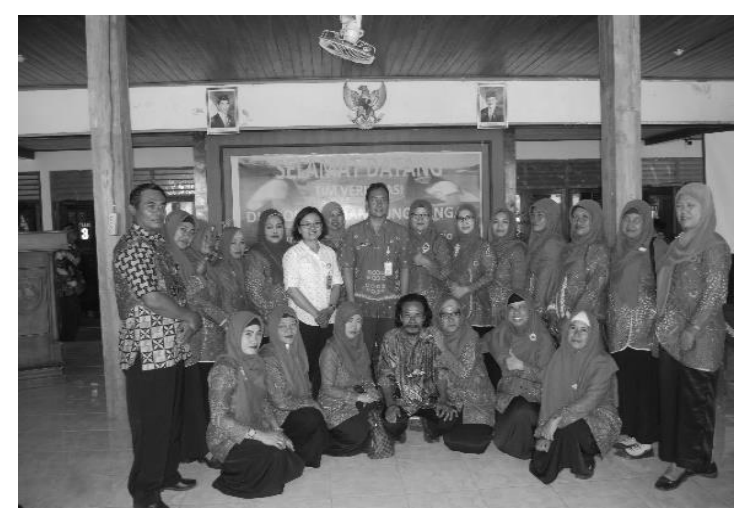

Gambar 3. Kader Jumantik (Juru Pemantau Jentik) 
Kader Jumantik dibentuk dengan diberikan arahan cara menjadi kader yang baik dan sigap dalam penanggulangan penyakit DBD. Disamping itu dilakukan pembentukan struktur pergerakan program, tetapi tidak merubah struktur pada keutuhan program dari kelurahan Kenep, Sukoharjo. Pelaksanaan program ini cukup menarik perhatian masyarakat saat dilaksanakan pemberian materi sehingga antusias melontarkan pertanyaan yang cukup penting untuk dibahas.

Disamping pemberian materi yang sudah dilaksanakan, perlunya penyuluhan lanjutan yang langsung terjun dilingkungan masyarakat. Penyuluhan lanjutan pada masyarakat bertujuan untuk mengetahui stimulasi yang sudah diberikan saat pematerian dan pembentukan kader. Selain itu, penyuluhan lanjutan ini akan diberikan pelatihan-pelatihan khusus yang bergiir, dimana daerah tersebut terdiri dari 3 wilayah yaitu lingkungan 1, lingkungan 2, dan lingkungan 3. Pada lingkungan satu terdiri dari RW 1, RW 2 dan RW 3; lingkungan dua terdiri dari RW 4, RW 5, dan RW 8; dan lingkungan tiga terdiri dari RW 6, RW 7, dan RW 9. Pembagian wilayah ini dilakukan untuk memudahkan masyarakat saling berkoordinasi tentang permasalahan-permasalahan yang terjadi didaerah tersebut khususnya dibagian kesehatan.

Saat penyuluhan dimasyarakat diberikan pelatihan khusus tentang Tree trap Mosquito yang bernama Ecovitrap. Pelatihan ini yang dimaksud yaitu pembuatan perangkap nyamuk dengan tiga fungsi yaitu di dalam rumah, di luar rumah dan khusus nyamuk dewasa.

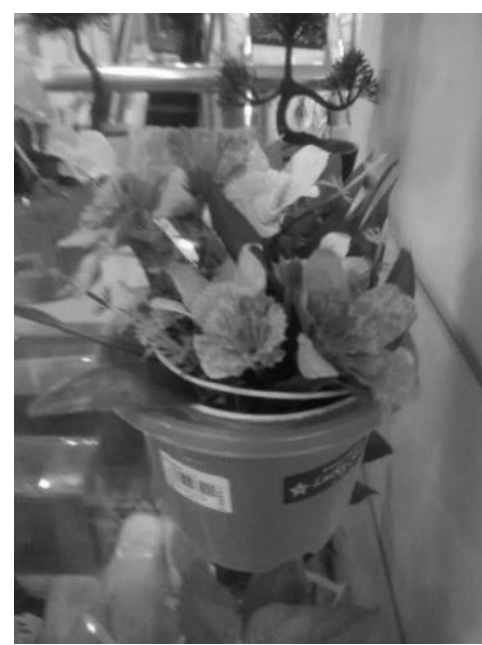

(a)

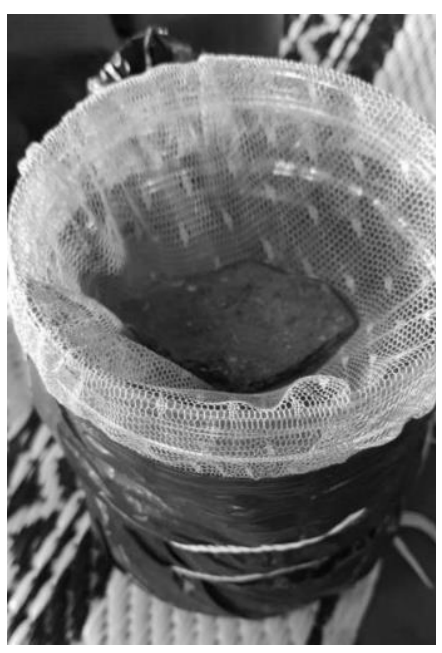

(b)

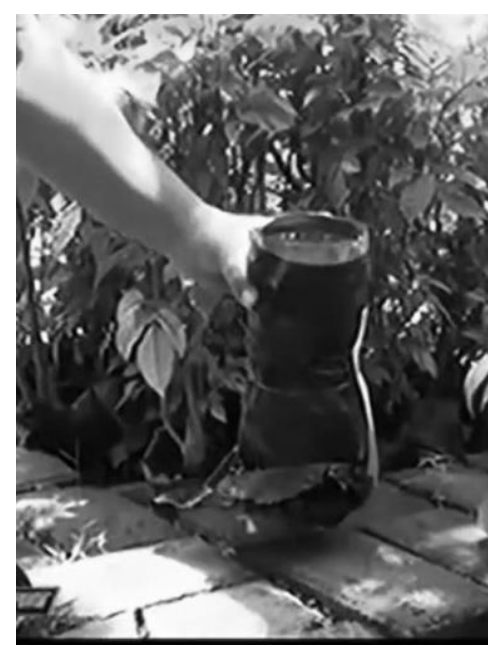

(c)

Gambar 4. Ecovitrap (a) dalam rumah (b) dan luar rumah (c) khusus nyamuk dewasa

Pelatihan diberikan agar dapat memberikan pengetahuan baru (Evelyn et al., 2018; Herlina et al., 2018) pada peserta. Pelatihan tentang Tree trap mosquito sangat bagus diterapkan di lingkungan Kelurahan Kenep ini karena berbasis ramah lingkungan yaitu penggunaan bahan bekas menjadi bahan nilai guna yang lebih tinggi, sehingga mampu menciptakan Education Sustainable for Development yang berpegang teguh pada pendidikan, lingkungan dan sosial.

Selain itu diberikan pelatihan dan pembagian bunga anti nyamuk yaitu jenis lavender (Lavandula sp.) dan zodia (Evodia sp.). Dipilih tanaman ini karena dinilai oleh banyak peneliti bahwa tenaman tersebut berpotensi untuk mengusir nyamuk dengan mengeluarkan aroma senyawa metabolit sekunder yang dimilikinya. Pada pelatihan ini dilakukan dengan cara memberikan pelatihan pembudidayaan atau cara perabanyakan tanaman anti nyamuk yang nantinya dapat digunakan sebagai anti nyamuk di lingkungan sekitar dan sisanya dapat dijualbelikan. Pada pelatihan ini masyarakat sangat antusias dalam mengikutinya. Disamping pelatihan-pelatihan juga dilakukan diskusi khusus jika masyarakat masih bingung tentang masalah bagaimana cara menangulangi nyamuk, membersihkan lingkungan yang baik dan akibat penyakit DBD jika menyerang pada masyarakat. 


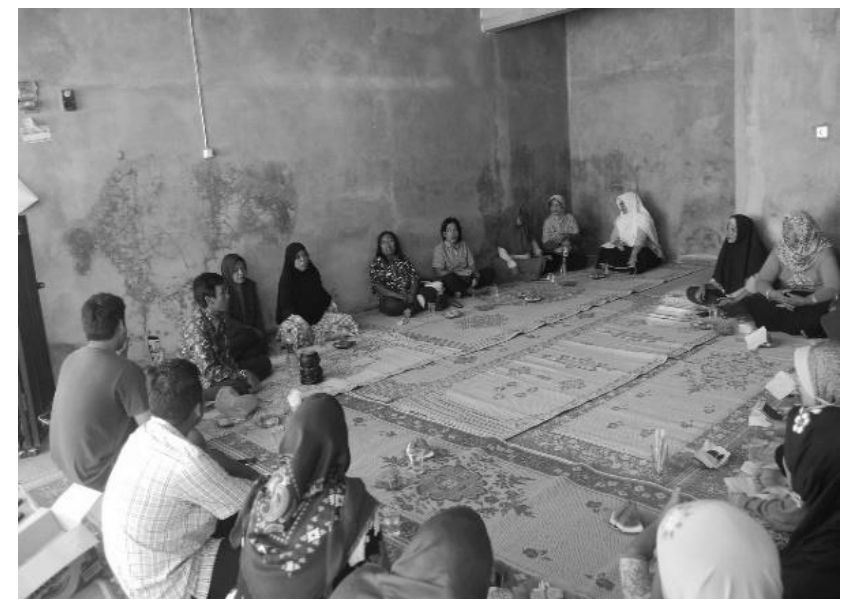

Gambar 5. Penyuluhan Masyarakat Lanjutan

Setelah ke penindaklanjutan dalam penyuluhan lanjutan masyarakat, dilakukan penyuluhan pada tingkat sekolah. Hal ini dilakukan untuk menciptakan generasi emas yang mandiri, kreatif, dan inovatif dalam menanggulangi permasalahan kesehatan lingkungan terutama penyakit DBD. Tindakan-tindakan ini diberikan pada SD N 1 Kenep, SD N 2 Kenep, dam SD N 3 Kenep. Cara yang dilakukan untuk mencapai tujuan yaitu dengan memeprkenalkan siswasiswi dengan bahan-bahan sampah yang tidak digunakan menjadi bahan yang memiliki nilai guna tinggi. Karena barang-barang bekas ini yang menjadi tempat perindukan nyamuk, sehingga nyamuk dapat berkembang biak dan dapat membawa penyakit DBD ke masyarakat. Untuk itu pengenalan bahan-bahan yang menjadi tempat perindukan nyamuk ini sangat penting, apalagi dapat digunakan menjadi bahan dengan nilai guna tinggi. Selain memperkenalkan, juga dilkukan permainan-permainan yang menarik tentunya dengan berbagai cara penentuan tempat perindukan, memilah sampah yang memiliki nilai guna dan pemanfaatannya serta menjadi cerdas kader cilik.

Dalam beberapa bulan pendampingan akan selalu dilakukan evaluasi demi keberlanjutan program, kami berharap kasus demam berdarah, malaria, dan penyakit-penyakit yang dibawa oleh nyamuk dapat berkurang, bahkan tidak terjadi kembali. Dengan demikian kami menganggap masyarakat Kenep, Kabupaten Sukoharjo telah berhasil menjalankan program pemberantasan nyamuk sebagai vektor penyakit. Kegiatan pendampingan dan sosialisasi serta penyuluhan pemberdayaan masyarakat hidup sehat bebas vektor nyamuk berbasis Education for Sustainable Development diharapkan dapat mencegah serta mengendalikan dari vektor nyamuk (DBD, Malaria, Penyakit Kuning dan Filariasis) di Kelurahan Kenep, Kabupaten Sukoharjo.

Program ini memiliki potensi yang sangat kuat dan penting untuk dilakukan, dikembangkan serta diterapkan, karena nantinya memberikan daya tarik yang baik untuk masyarakat dalam memahami pembelajaran dan pengaplikasiannya. Program tersebut juga diharapkan dapat menciptakan desa sehat bebas dari vektor nyamuk, dengan luaran meningkatkan pengetahuan para kader Jumantik (Juru Pengamatan Jentik) di Kelurahan Kenep, Sukoharjo Jawa Tengah dan meningkatkan pengetahuan dan kesadaran pada warga desa pentingnya pembelajaran tentang vektor nyamuk dan penyebab faktor lainnya. Belum lagi, Kelurahan Kenep juga akan menjadi rujukan, role model, atau bentuk representasi desa yang telah berhasil mewujudkan desa bebas vektor nyamuk. Sehinga diharapkan masyarakat di wilayah lain dapat terinspirasi untuk tergerak dan sadar akan pentingnya kesehatan lingkungan.

\section{KESIMPULAN}

Program pemberdayaan masyarakat hidup sehat telah diterapkan melalui pembelajaran yang edukatif, kreatif dan inovatif dengan pemahaman yang menarik sehingga masyarakat lebih 
paham dan mengerti tujuan program dalam mewujudkan desa sehat bebas vektor nyamuk berbasis Education for Sustainable Development di Kelurahan Kenep, Sukoharjo Jawa Tengah.

Pemberdayaan masyarakat hidup sehat melalui konsep Ecohealth Village memiliki potensi besar untuk diterapkan meliputi tataran sosial, ekonomi, lingkungan serta kesehatan, sehingga membentuk kesadaran dalam mencegah penyakit-penyakit yang disebabkan oleh vektor nyamuk terutama di Kelurahan Kenep, Sukoharjo Jawa Tengah. Tidak menutup kemungkinan potensi tersebut melalui pembelajaran yang aktif dan kreatif, masyarakat Kenep dapat menjadi percontohan atau representasi dari keberhasilan pengembangan program.

\section{UCAPAN TERIMA KASIH}

Ucapan terima kasih kepada Direktorat Pengabdian Kepada Masyarakat Universitas Gadjah Mada dan UKM Gama Cendekia UGM sebagai wadah pengembangan ilmu dalam menerapkan program pengabdian serta Keluarahan Kenep, Kabupaten Sukoharjo, Jawa Tengah, sebagai tempat pengabdian kepada masyarakat.

\section{DAFTAR PUSTAKA}

1. Dainur. 1992. Materi-materi Pokok Ilmu Kesehatan Masyarakat. Jakarta: Widya Medika.

2. Dinas Kesehatan Jawa Tengah. 2017. Profil Kesehatan Provinsi Jawa Tengah 2017. Jawa Tengah: Dinas Kesehatan Jawa Tengah.

3. Dinas Kesehatan Kabupaten Sukoharjo. 2016. Profil Kesehatan Kabupaten Sukoharjo Tahun 2015. Sukoharjo: Dinas Kesehatan Kabupaten Sukoharjo.

4. Evelyn, E. Saputra, Komalasari, \& S. Utami. 2018. Community training in dishwashing-liquid soap making from waste cooking oil. Riau Journal of Empowerment 1(2): 67-74. https://doi.org/10.31258/raje.1.2.9

5. Giyantolin, A. Alfianto, S. H. Poerwanto, A. I. P. Kusumawardani, K. P. Kinasih, \& M. M. Rarahjo. 2018. ECOHEALTH VILLAGE: Program Desa Sehat Bebas Vektor Nyamuk di Desa Caturtunggal, Depok, Kabupaten Sleman. Dipresentasikan pada SEMNAS PPM Universitas Airlangga.

6. Herlina, S., W. Winarti, \& C. Wahyudi. 2018. Meningkatkan pengetahuan dan kemampuan kader kesehatan melalui pelatihan bantuan hidup dasar. Riau Journal of Empowerment 1(2): 8590. https://doi.org/10.31258/raje.1.2.11

7. Kementerian Kesehatan RI. 2010. Buletin Jendela Epidemiologi: Manajemen Demam Berdarrah Berbasis Wilayah. Pusat Data dan Survailans Epidemiologi Kementerian Kesehatan RI, 2.

8. Kementerian Kesehatan RI. 2018. Indonesia Health Profile 2017. Jakarta: Ministry of Health Indonesia.

9. Kementerian Kesehatan RI. 2019. Profil Kesehatan Indonesia 2018. http://www.depkes.go.id/resources/download/pusdatin/profil-kesehatan-indonesia/Data-danInformasi_Profil-Kesehatan-Indonesia-2018.pdf. Diakses pada 15 April 2019.

10. Suwito, A. 2008. Nyamuk (Diptera: Culicidae) Taman Nasional Bogani Nani Wartabone, Sulawesi Utara: Keragaman, Status dan Habitatnya. Jurnal Fauna Tropika 17(1): 27-34.

11. UNESCO. 2005. Guidelines and recommendations for reorienting teacher education to address sustainability, UNESCO education for sustainable development in action. Technical Paper No.4. Paris: UNESCO. 